\title{
Memories and reflections on the "socialist" urban center
}

\author{
Zlatina Bogdanova*
}

\begin{tabular}{|c|c|}
\hline A R T I C L E I N F O & A B S T R A C T \\
\hline $\begin{array}{l}\text { Received: } \\
\text { June 24, } 2021\end{array}$ & $\begin{array}{l}\text { Based on empirical research in Asenovgrad, this paper } \\
\text { discusses socially constructed spaces during socialism and } \\
\text { how they were used to impose and legitimize power. It }\end{array}$ \\
\hline $\begin{array}{l}\text { Received in revised } \\
\text { form: } \\
\text { October } 29,2021\end{array}$ & $\begin{array}{l}\text { proposes alternate perspectives towards socialism and its } \\
\text { material culture expressed in the creation of modern } \\
\text { architectural ensembles in the town center. Socialist } \\
\text { architecture was a power statement which imposed new }\end{array}$ \\
\hline Accepted: & values and ideas. These buildings were markers of state \\
\hline November 7, 2021 & $\begin{array}{l}\text { authority which sent a powerful message for the renewal } \\
\text { of society by breaking away from older, pre-socialist }\end{array}$ \\
\hline Published online: & traditions. Among the issues examined here is the \\
\hline November 27, 2021 & $\begin{array}{l}\text { significance of the urban square and its surrounding } \\
\text { buildings for residents of Asenovgrad today; how is the } \\
\text { town's center perceived in the collective memory? The } \\
\text { analysis concludes by exploring the relationship between } \\
\text { architecture and ideology in the way social reality was } \\
\text { constructed, instrumentalized and offering insight into } \\
\text { how the socialist regime was legitimized through material } \\
\text { culture, artifacts, and buildings. }\end{array}$ \\
\hline
\end{tabular}

Keywords: socialism, post-socialism, small town, urban center, ideology, architecture, memory, heritage.

To cite this article: Bogdanova, Z. (2021). Memories and reflections on the "socialist" urban center. Urban $a, 22,87-103$. Retrieved from http://www.urbanauapp.org https://doi.org/10.47785/urbana.8.2021

\footnotetext{
*zlatina_bogdanova@abv.bg Bulgarian Academy of Sciences, Institute of Ethnology and Folklore, Studies with Ethnographic Museum, Ethnology of Socialism and Post-Socialism Department. This article is based on a presentation given at the International Conference "(Re)thinking Socialism: Knowledge, Memory and Oblivion of the Socialist Past" (November 7-9, 2019, Sofia), organized by the "Ethnology of socialism and post-socialism" Department at the Institute of Ethnology and Folklore Studies with Ethnographic Museum at the Bulgarian Academy of Sciences.
} 


\section{Introduction}

In anthropological research, places and landscapes express individual memories and stories of people; they form the basis of shared identities but can also become a means of imposing power. They can be perceived as a material reflection of previous power relations. Based on empirical research in Asenovgrad, this article examines one element of the urban environment - the architectural landscape of the town center as the controversial and "undesirable" heritage of socialism. The fundamental research questions are how people rethink the town center and corresponding architectural heritage today, how it influences their perception of the past, and how urban memory is kept and recreated through new projects and activities. This discussion is ever more relevant in the postsocialist context in which Bulgaria is an EU member since 2007, resulting in a combination of modern and old in the urban landscape of Bulgarian cities.

\section{Methodology}

This case study is based on the Anthropology at Home method. I have used my insider position (as a researcher permanently residing in Asenovgrad) to gain access to respondents, observe everyday lifestyles and special events that take place in the town center. My family history in Asenovgrad is also among the personal characteristics that have influenced the research: two of the outstanding buildings that remained in the center as a legacy from the pre-socialist era were commissioned and owned by my great grandfather Pavel Boev, an affluent wine-producer. These buildings were designed by architect Boyan Chinkov ${ }^{1}$ who was politically persecuted and imprisoned for a short period after 1944 for telling jokes about the communist rulers. Therefore, my family background has provided me with valuable contacts and access to information.

The survey methodology includes biographical interviews with two key male respondents, born in the early 1940s; informal conversations with two middle-aged women working in central institutions - a librarian and a museum curator. Additional information was collected through semi-structured interviews with three representatives of the younger generation in Asenovgrad - young people born at the border and after 1989, members of the youth organization of the Bulgarian Socialist Party, the heir of the Communist Party in Bulgaria after 1989. At the time of recording the interviews (summer of 2019) the three respondents (a woman and two men) were actively campaigning for the socialist party candidates running for mayor and municipal council in Asenovgrad. One of the respondents - a 20 years old male University student was then a candidate for councilor. I observed and interviewed them while they were distributing party materials from the BSP campaign tent, located in the center, where many people were passing by.

Therefore, the small sample of seven respondents included representatives of three generations living in Asenovgrad. The two men from the oldest generation were young professionals working in the central part of the town throughout the 1970s and 1980s. The two middle-aged female respondents are still working in central institutions, and hence, their professional careers are also connected to the town center. The representatives of the younger generation were involved in political campaigning in the

\footnotetext{
${ }^{1}$ Architect Boyan Chinkov was a graduate of the Berlin Technical School who began his career in Asenovgrad. He is recognized as one of the leading architects in Bulgaria. I live in the building designed to be his graduation project from 1926 .
} 
center as youth members of the BSP. In all cases, I sought out the personal and professional relationships and connections people had with the central part of the town. My family history is as well related to the center.

The research accentuates the activities of a local association called Stanimashka fotografchiynitsa (Photography of Stanimaka) which has so far developed different formats for the conservation of urban heritage and cultural memory. These include a Facebook group, a video series ${ }^{2}$ uploaded to YouTube and retro festivals. The association has successfully carried out more than a few donation campaigns for saving valuable artifacts (e.g. the redemption of an old carriage) and restoring local monuments of culture (e.g. a water fountain and church icons that date back to the $19^{\text {th }}$ century). They also organized a photo collage exhibition as a fund raiser campaign in 2021 and printed a calendar with archival photographs two years ago. The main observations and studies on this topic were conducted in the period 2019-2021.

\section{The architectural signs of socialism}

Following the Soviet model of the 1930s, socialist realism became the adopted cultural form in Bulgaria. This was a radical break with previous traditions and cultural patterns. Initially, the new architectural style was opposed to the modernism and formalism styles fashionable in Western art, which was viewed as bourgeois. This, in turn, resulted in a unification and de-personalization of urban landscapes; this is particularly visible in the "socialist" urban center. The period of socialist realism lasted until the plenary session of the Communist Party in April 1956. In the following years, Western modernism was rehabilitated and exerted a great influence on art and architecture in Bulgaria.

Among the widely recognized architectural signs of socialism were brutalism, dehumanization, coercion, alienation, monotony and megalomania reflected in the mass production, panel construction and design uniformity of public spaces, industrial/residential zones and representative buildings (Harbova, 2003). One of the well-known late examples of neoclassicism and a good illustration of the aforementioned traits of socialist architecture is Bucharest's monolithic Palace of the Parliament made of 700,000 tonne concrete, built by thousands of soldiers and "volunteers", and designed by a team of 700 architects led by Anca Petrescu for Romania's former communist dictator, Nicolae Ceaușescu. Started in 1984, the construction of the Palace was not completed until 1997. Today, not only has the Palace of the Parliament remained one of the city's main landmarks, but it has also made a record as the second largest administrative building in the world after the building of the Pentagon in the United States (Torre, 2020). ${ }^{3}$ Another representative building of the era is the Palace of Culture and Science in central Warsaw, Poland. Designed by the Soviet architect Lev Rudnev, this socialist realist skyscraper was originally known as the Joseph Stalin's Palace of Culture and Science (Pałac Kultury i Nauki imienia Józefa Stalina). Said to be "gift from the Soviet people", the Palace has become one of the most controversial examples of Stalinist

\footnotetext{
${ }^{2}$ I have also volunteered to help in the production of the video series by translating the texts for the English subtitles.

${ }^{3}$ For more illustrations of socialist architecture, see "Eastern Bloc Architecture: 50 Buildings that Defined an Era", a collaborative series by The Calvert Journal and ArchDaily:

https://www.archdaily.com/tag/eastern-bloc-architecture-50-buildings-that-defined-an-era, Accessed 29 Oct 2021.
} 
architecture built in the period 1952-1955. This structure is still the fourth largest building in the European Union (Kępa, 2015).

\section{The architectural heritage of socialism}

Most buildings and town squares built after 1944 in urban centers were invariably associated with the ideology of communism. This also entailed the imposition and legitimization of power dynamics, centralizing governance, and a standardization and homogenization of the social milieu. Urban planning and architecture from the socialist period are considered here to be a manifesto of the communist government which imposed new values in Bulgaria in the period from 1944 to 1989. As conduits of the regime, monumental buildings from this era communicated a powerful message for the reorganization of public space and social relations by breaking with older, pre-socialist traditions. Henry Lefebvre theoretically reflects on the interaction between City and State by pointing to the territorial development, urban planning, and production of social space as one of the mechanisms for legitimizing and maintaining power:

The production of a social space as such, an (artificial) edifice of hierarchically ordered institutions, of laws and conventions upheld by "values" that are communicated through the national language. This social architecture, this political monumentality, is the State itself, a pyramid that carries at its apex the political leader - a concrete abstraction, full of symbols, the source of an intense circulation of information and messages, "spiritual" exchanges, representations, ideology, knowledge bound up with power. (Lefebvre, 2009, p. 224)

The theme of socialist monuments, buildings, and artifacts as well as their interpretation in a post-socialist context has been discussed previously in Bulgarian ethnology and sociology (cf. Harbova, 2003; Nikolov, 2003; Vukov, 2018; Luleva, 2018; Vasileva and Kaleva, 2018; Stanoeva, 2016). Bulgarian Architects Emilia Kaleva and Todor Bulev have also addressed this issue in the Journal entitled Architecture.

In some of the aforementioned works, monuments from before the changes in 1989 are conceptualized as "socialist heritage", even though what this concept means is still unclear and contradictory. There is no clear state policy regarding the preservation of these monuments and buildings which adds to the complexity of the problem. The concept of "heritage" is also difficult to apply to material culture inherited from the recent past, and the need to find a new approach to the "unwanted" heritage of socialism is increasingly felt (Vukov and Toncheva, 2006, p.132).

Architect Emilia Kaleva analyzes some projects resulting from socialist urban planning through the discourse of heritage in her article "Socialist monuments and public urban spaces in the post-socialist Bulgarian city" (2015). She views the town square as a permanent element of city topography from the past to the present. Public buildings and central urban spaces are key conditions for social life in any city. Furthermore, such central public spaces are where changes of political and ideological regimes are felt most strongly. The socialist regime gave birth to a distinctive "architectural epoch" - a term defined as directly related to a specific social system (Koeva, 1985). According to Kaleva, the period of socialism can be regarded as a complete architectural era with a clear beginning and end. The architectural priorities of the socialist regime consisted of 
planning and constructing public, representative buildings as natural characteristics of the urban environment. The territorial organization was established through a series of state documents and the gradual creation of special design departments. This development was part of the general mechanism for building socialism. During the strongest period of the planned economy, towards the end of the 1970s, each city had its own function and profile - set in advance, guided and controlled. Planning was not done in isolation, but as part of establishing a larger territorial and economic urban system where each settlement had industrial and residential districts, as well as zones for recreation, public services, transportation, communications, etc. Therefore, all settlements in socialist Bulgaria were designed as a unified system - interconnected, hierarchically rated and specialized (Kaleva, 2015, p. 19).

\section{Asenovgrad during the era of socialism}

Bulgarian architecture from the period of socialism (1944-1989) was mainly oriented around urban planning and developing city centers. As a result, the outer appearance of small and medium-sized towns has been significantly changed; town centers were almost completely rebuilt while industrial and residential complexes came into sight in urban peripheries. The specific modernistic urban planning corresponded to the socialist context. These tendencies are clearly visible in Asenovgrad - a municipal center located in the district of Plovdiv, South Central Region. ${ }^{4}$ Asenovgrad is the largest urban settlement in the Rhodopes and the second most populous town after Plovdiv. ${ }^{5}$ Until 1934, it was called Stanimaka from the Greek toponym $\Sigma \tau \varepsilon v \eta \dot{\mu} \mu \chi 0 \varsigma$ (Stenimachos). The town was renamed Asenovgrad in honor of Tsar Ivan Asen II, who ruled between 1218 and 1241. He expanded Asen's fortress - a medieval fortification and important defense post on the southern border of the Second Bulgarian Kingdom. (Fig. 1). Asenovgrad is often called "the little Jerusalem" due to its many churches and chapels. The town is ethnically mixed and multicultural - generations of Bulgarians, Roma, and Turks have coexisted for centuries. After 1989, the private fashion industry expanded and Asenovgrad gained national prominence with a large number of enterprises and shops for formal wear, especially wedding gowns and accessories.

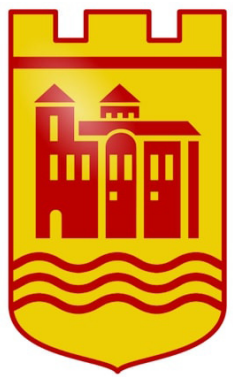

Fig. 1 Coat of arms of the Asenovgrad Municipality.

In the late 1970s and early 1980s, the modern town center of Asenovgrad took shape by completely altering the street infrastructure. The new buildings in the town

\footnotetext{
${ }^{4}$ See the official website of the Municipality of Asenovgrad: https:/www.asenovgrad.bg/bg/

5 The population of the town is 48,719 according to official sources from 31 December, 2018.
} 
center were designed to meet several important functions. The Municipal Administration building of the mid 80s handled administrative tasks, The Party House was the political center, the Town Library (opened 1982) was for culture and education, and the Hotel "Asenovets" (completed 1973) was for economic development related to international tourism. This massive construction corresponds to trends in socialist planning, particularly from the 1970s onwards, "when not just monuments were built, but entire memorial complexes, monumental ensembles, combining urban planning, architecture and monumental plastic art" (Kaleva, 2015, p. 19). The central buildings in Asenovgrad - the Town Hall, the Library and the Police Department ${ }^{6}$ (the former Party House, once officially called the Municipal Committee of the Bulgarian Communist Party) - were located on three levels. On the second and third levels there were mosaic-covered floors overlooking the pedestrian main street. The expanded central promenade was called "Trakia" square during socialism. Since 1989, it bears the name of the Bulgarian Academician Nikolay Haytov - a revered writer whose bust-monument is located in front of the former Town Hall now housing the Municipal Tourist Center.

The Asenovgrad library still has a brochure from 1986 dedicated to the socialist vision of tow town. In the preface the victory over fascism and the subsequent imposition of the communist rule are praised in the context of the new urban image (Kostadinov, 1986, p.7). The photographs ${ }^{7}$ in the brochure represent the modern, socialist daily lives of townspeople against the background of new industries, workshops, classrooms, and playgrounds. The new center had already been finalized and was well illustrated in the publication. (Figs. 2 - 5).

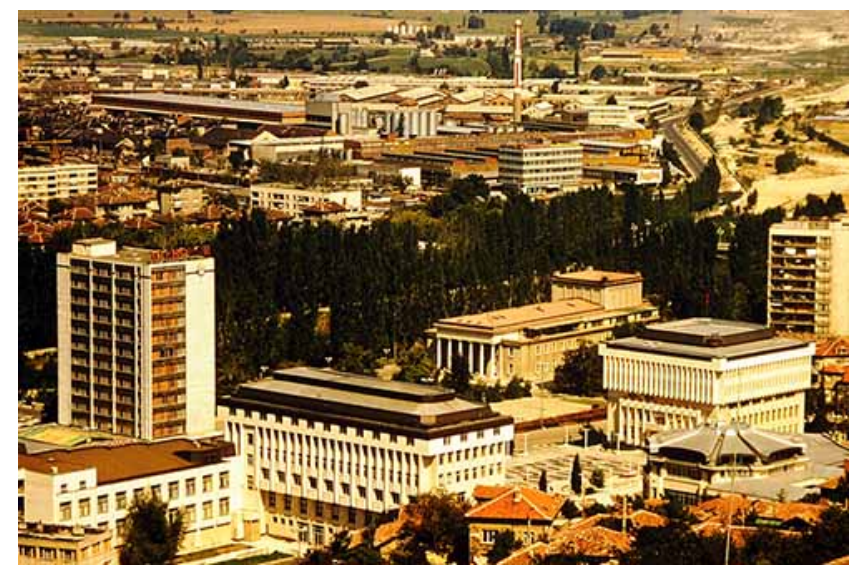

Fig. 2 Panoramic view of Asenovgrad from the 1980s. Photo: Boris Shopov.

\footnotetext{
${ }^{6}$ The Police Department was moved to the building of the former Party House in 2006. The official opening was attended by the Minister of the Interior, Rumen Petkov.

${ }^{7}$ In 2019 I contacted Boris Shopov - one of the photographers who contributed photographs to the Album. He was kind enough to send these photos kept in his personal archive.
} 


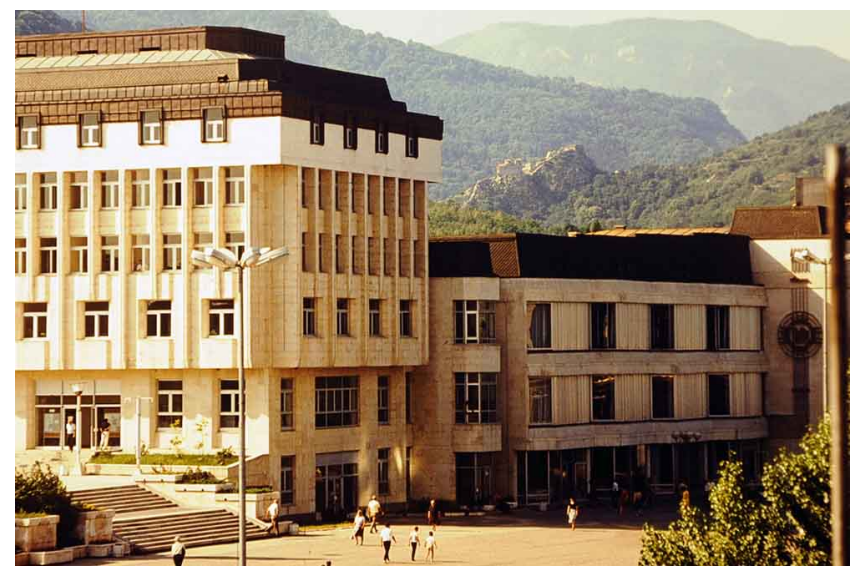

Fig. 3 In the foreground - the Town Hall against the background of Asen's Fortress, 1986. Photo: Boris Shopov.

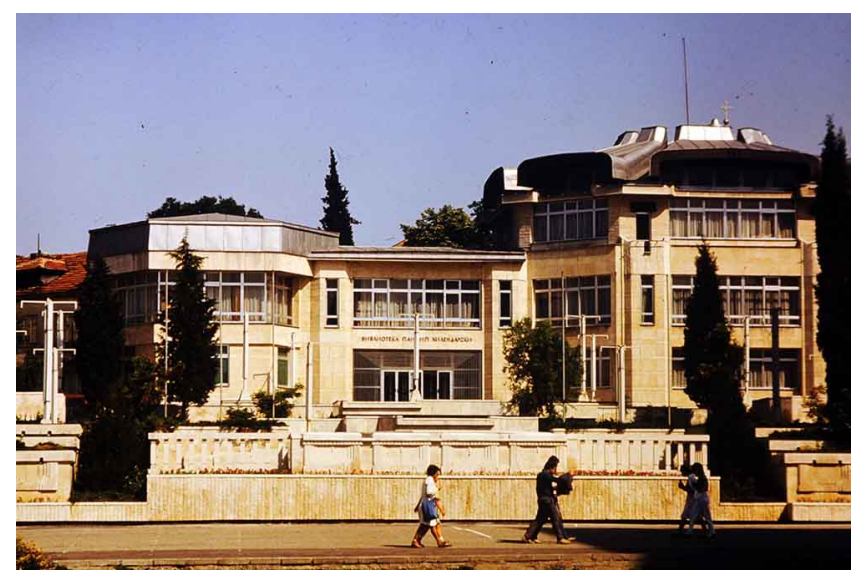

Fig. 4 "Paisii Hilendarski” Town Library, 1986. Photo: Boris Shopov.

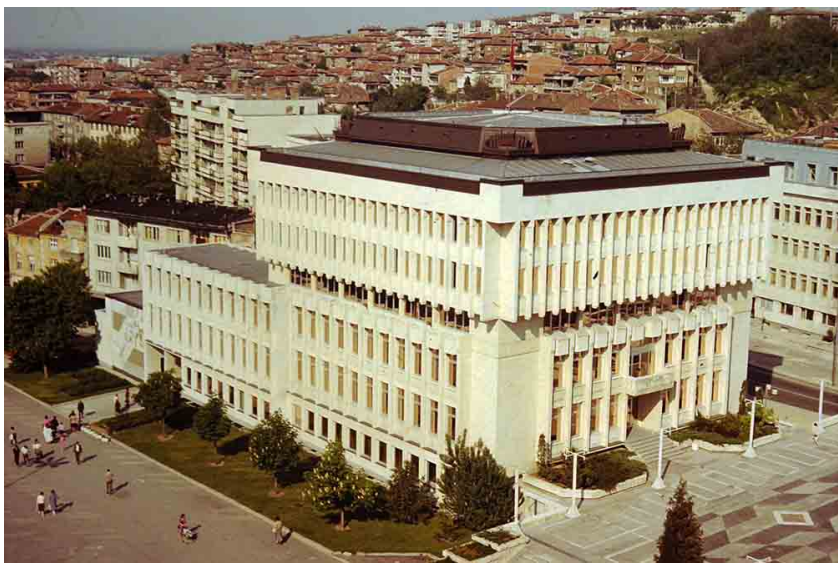

Fig. 5 The Party House, 1986. Photo: Boris Shopov

All buildings discussed in the paper are still standing and used for administrative/public services and functions. The only exception is "Asenovets" hotel, 
which is still in place, but no longer functions as a hotel. It has remained as one of the "silent" abandoned monuments of socialism. ${ }^{8}$

Conceived as emblematic urban accents, these "socialist" buildings in the central square continue to dominate the cityscape. Over time, they have become an integral part of everyday urban life. The main reason is that these buildings connect key urban spaces with festive and commemorative events, as well as with political, cultural, advertising, and commercial campaigns. A strong spatial, functional and socio-cultural connection has been established which gives the town square a specific image.

To assess the impact of these buildings, I interviewed representatives of the younger generation born on the border of 1989. These respondents have no life experience under socialism. With regard to the buildings in the urban center, they found it hard to distinguish different architectural epochs; that is, they could not say which building was built prior to 1945 or much later. While working on this topic, I also met two people whose work and life were directly related to the center of Asenovgrad during the socialist era. ${ }^{9}$ The professional path of both respondents was influenced by the local party organization of the Bulgarian communists. Ivan (born 1940) is a civil engineer still working in Plovdiv at the time of our meeting. Under socialism, he was in charge of the construction of the architectural ensemble in the town center which architect Racho Stoyanov designed in the 1980s. It all began when he was appointed to this position due to his outstanding professional qualities which impressed the first secretary of the party in Asenovgrad. Although my respondent was never a party member, he was nonetheless commissioned to carry out this essential assignment. Throughout the project, Ivan often came into conflict with the party members, especially the first secretary, whom he called a "donkey" in his pamphlet written after the democratic changes of 1989. Ivan took part in the first anti-communist rally in Asenovgrad organized by the Agrarian Union in support of the "perestroika" after November 10, 1989. From the stairs of the central square, right in front of the buildings he had constructed, he delivered the first opposition speech against the ruling Communist Party. In the years of early democracy, Ivan remained a supporter of the regime change, but had no ambitions for a political career of his own.

In the years after 1989 the city center "took up" the burden of the transition and became the primary target for expressing opposition sentiments. Vukov and Toncheva have also noted the socio-political charge of urban central squares: "In the years immediately after the political changes in Bulgaria, the main squares and city locations were already turned into arenas for voicing opposition to the former ideology and for expressing support for issues of democratization raised by the newly emerged political groups. In these meetings many of the monuments and ideological representations were either toppled or suffered diverse forms of desecration" (Vukov and Toncheva, 2006, p. 125).

The other key respondent whom I interviewed on this topic was Hristo (born 1942), a former party activist whose career had been fully associated with the party

\footnotetext{
${ }^{8}$ For a discussion on the ruins of socialism, see Lahusen, 2006.

${ }^{9}$ In the two interviews recorded in October 2019, I used the biographical method which relates social change and structure to individual action and life experiences.
} 
organization in Asenovgrad. In the "Komsomol," ${ }^{10}$ he organized youth activities and later became the director of the local branch of "Balkantourist" opened on February, 17, 1973. (Fig. 6).

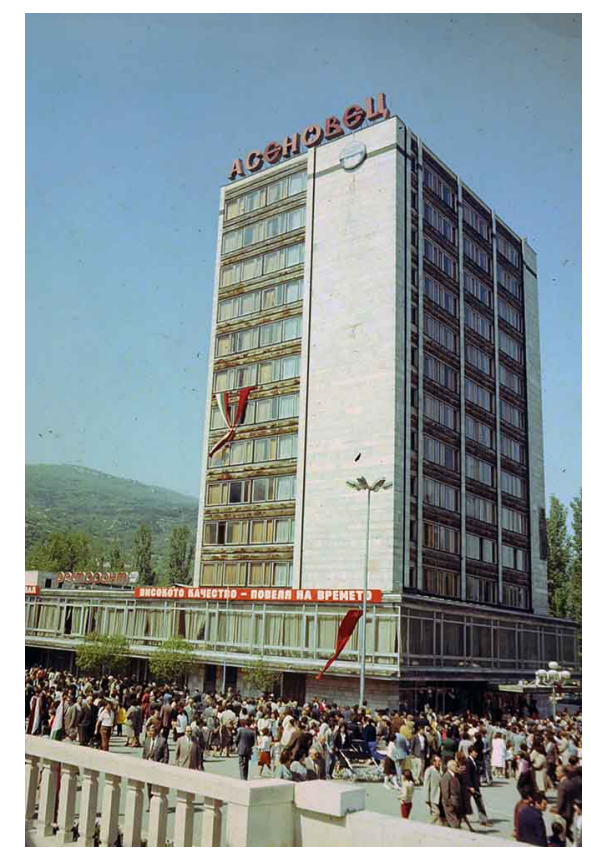

Fig. 6 "Asenovets" Hotel, 1986. Photo: Boris Shopov.

Located opposite the architectural ensemble in the town center, this multi-storied building corresponded to the trend for the "Sovietization" of Asenovgrad. Hristo remembered how it operated during socialism under the "Balkantourist" label; groups of Russian and Greek tourists were welcomed daily while the staff spoke several languages and provided the best service. The hotel shop offered luxury products, both imported and those made in Bulgaria. Later, Hristo pursued a career in the local party organization which had offices in the Party House where he was responsible for organizing the party propaganda campaigns.

Hristo's memories of socialism contrast with those of Ivan because of their different positions vis-à-vis the Party. While Hirsto enjoyed the privileges of being a party member and activist, Ivan had opposed the local party officials even before the democratic changes. The town square is where their biographies intersect - the architectural ensemble built by the one and professionally inhabited by the other.

\section{Photography of Stanimaka on Facebook}

As residents of a post-socialist town, the people of Asenovgrad are searching for their new historical identity. This endeavor is mostly visible from the materials published in a Facebook group called Stanimashka fotografchiynitsa (Photography of Stanimaka),

\footnotetext{
10 "Komsomol" was a popular name for the communist youth organization in Bulgarian which operated until 1990.

11 "Balkantourist" (1948-1995) was a state tourist enterprise which monopolized the tourist market in Bulgaria. It had branches in many Bulgarian towns and developed international tourism mainly within the former socialist bloc.
} 
which has been active in the virtual space since early $2015 .^{12}$ There are currently more than 5,000 members of this group. With the ambition of preserving the cultural memory of Asenovgrad, people regularly post old photos and documents collected from personal archives. The group's mission statement is as follows: "We collect, preserve and illustrate the past of Asenovgrad in photos. Help us transfer to the future the best moments of Asenovgrad and the region. Tell your exciting story of the photo you post."

As a rule, members only publish old photos related to Asenovgrad - streets, buildings, landscapes, etc. Family albums and school photos are often shared, life stories and memories provoke discussions, and important events in the history of the community are highlighted. People frequently comment on photos that illustrate urban landscapes, particularly the town center. There is a widely held view that the old, pre-socialist historic center was much more picturesque and cozier. The socialist urbanization project destroyed many streets and houses, some of which were associated with emblematic historical figures. Thus, not only "Stălbena" Street was wiped out, but also a great part of Asenovgrad's cultural memory (Fig. 7).

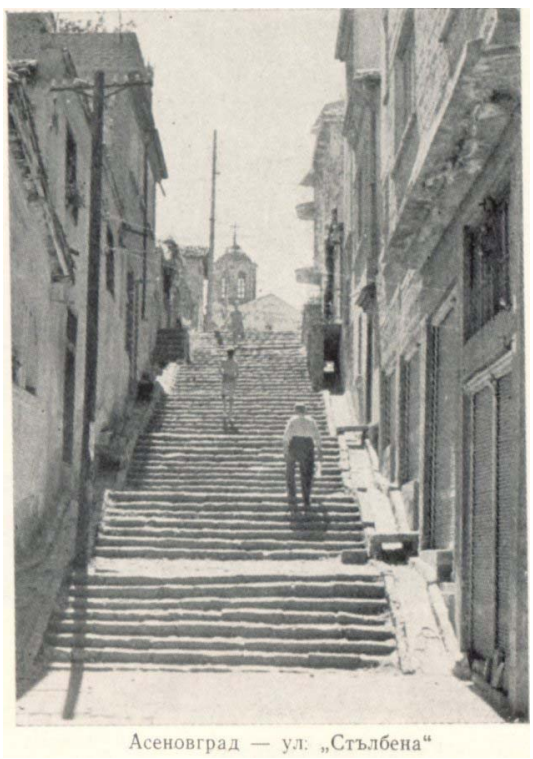

Fig. 7 "Stălbena" Street with "St. Dimitar" Church on top. Date: before 1960. Source: Personal archive of Atanas Kendev. ${ }^{13}$

\section{The old vs. the new town center}

In 2019, the founders of the group formally registered Stanimashka fotografchiynitsa as an Association, which since then has actively engaged in the promotion and research of the town's culture and places of memory from the recent past. The Association organized a street retro festival called "20s of the XX century" in September 25-27, 2020. One of the key events was the premier of a short video entitled "Lost Asenovgrad" - Part One".

\footnotetext{
${ }^{12}$ See the Facebook group Stanimashka fotografchiynitsa (Станимашка фотографчийница): https://www.facebook.com/groups/723652627742915

13 Atanas Kendev is one of the founding members of the Facebook group and later the Association Stanimashka fotografchiynitsa. He has studied the urban changes around the creation of the historic center in the period 1922-1944 and its destruction from 1972 to 1982. Kendev is the author of the narrated texts in the aforementioned video series “Lost Asenovgrad” („Изгубеният Асеновград”) uploaded to YouTube.
} 
In the announcement before the screening, an emphasis was placed on changes in the historic urban core: "In the architectural history of the town center there is a watershed the late 70s. Then a complete, beautiful and harmonious center was largely demolished to build the concrete socialist center." 14

Since then, the Association has created a series of short episodes which were uploaded to YouTube. The first episode illustrates the architectural landmarks in Asenovgrad from the early twentieth century and the narrator states the following: "All of the illustrated buildings were built in this period, and we could certainly say - what was established in the first half of the twentieth century is of a world class quality, and these buildings are valuable monuments of Bulgarian architecture and culture. Unfortunately, in the mid-1970s, something irreparable happened in the town. A fully built, harmonious town center - a witness to past prosperity - was destroyed. Beautiful, proud, healthy residential and public buildings were being demolished in order to build a new center. At the beginning of the twenty-first century, the list of cultural monuments in Asenovgrad contains of a hundred sites. If the old city center had not been destroyed, they would have been close to two hundred. Cultural monuments are the peaks in the biography of the urban heritage. Many of them have been lost, preserved only in photos and memories." 15

In the virtual space of Stanimashka fotografchiynitsa, people often share photos of the historic center which existed until 1972. (Fig. 8). In the period from 1973 to 1982, a new center representative of the architectural era of socialism emerged. Today, this center is openly criticized in the group's discussions. For example, K. P. wrote a post under a picture of the old center: "Now is the time to throw out the center and restore some elements of the dignity of Asenovgrad". Another user angrily commented: "Of course, in the name of the Party and the people some architectural idiocy was erected, which we "enjoy" to this day".

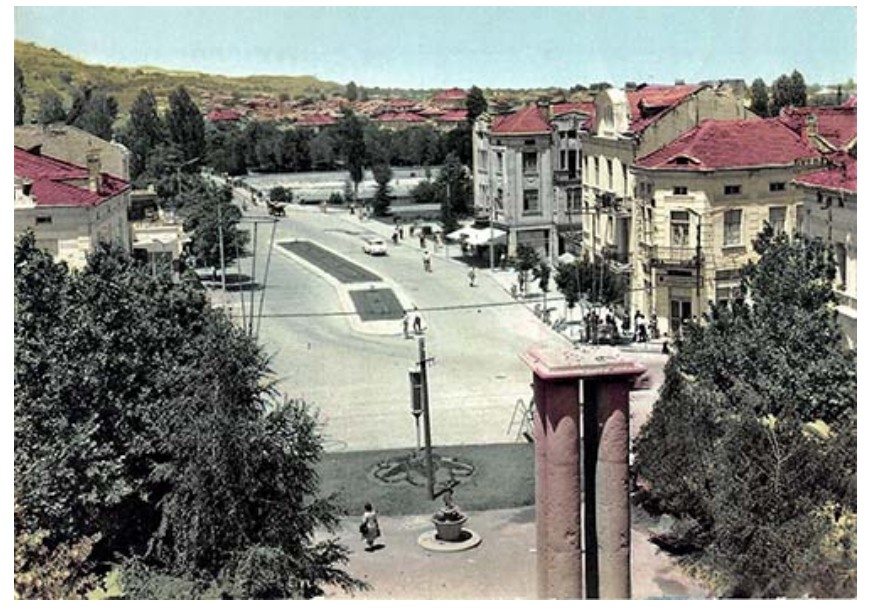

Fig. 8 Postcard from Asenovgrad: "Trakia" Square. (In the foreground - the Military Monument, removed during the construction of the new center). Date: 1963. Source: FB group Stanimashka fotografchiynitsa

\footnotetext{
${ }^{14}$ The program of the festival "Street retro-festival "20s of the XX century in Stanimaka" was published in the newspaper Vestitel, year XXIII, issue 1010, September 25 - October 1, 2020, p. 4.

${ }^{15}$ See the Episode 1, "Lost Asenovgrad": https://www.youtube.com/watch?v=DpWOxAb1ygA\&t=210s (accessed March 20, 2021).
} 
The new town center was the result of a party decision and, as might be expected, it was designed and built without public input or discussion, as was the practice during socialism. In an attempt to "turn back time" and undertake a revision of the centralized decision-making of the past, two members of Stanimashka fotografchiynitsa, Krum Bumbarov and Hristo Kovatliev, have created interesting photo collages - one original way of reflecting and illustrating changes in the urban environment over the years. (Figs. 9 - 10).

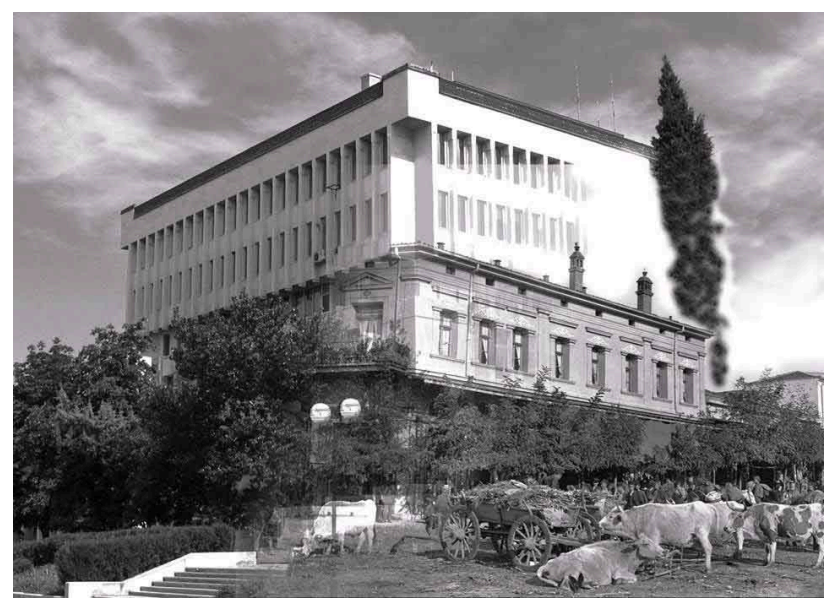

Fig. 9 Photo collage made by Krum Bumbarov. Source: Facebook gourp Stanimashka fotografchiynitsa (Станимашка фотографчийница).

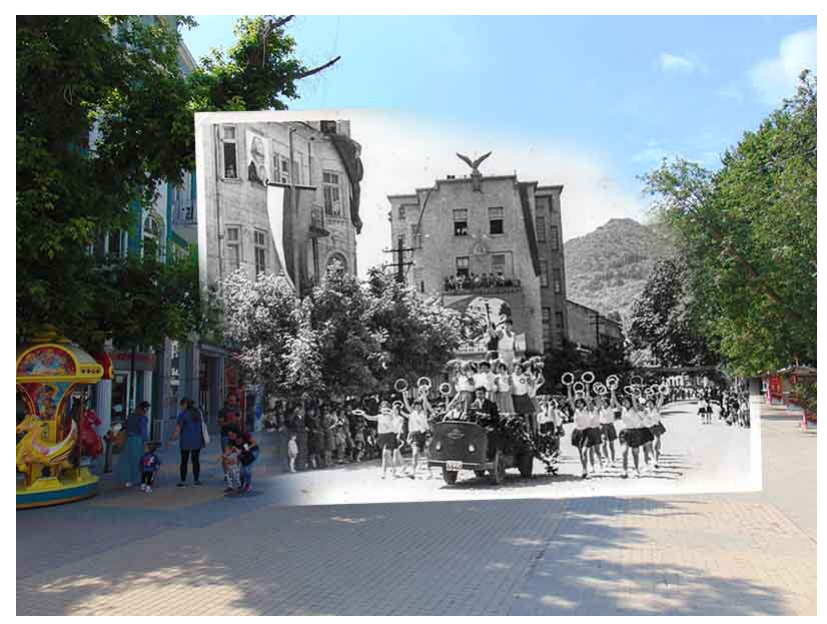

Fig. 10 Photo collage made by Hristo Kovatliev. The building in the center is locally known as "Orela" ("the Eagle") because of the eagle sculpture on top. Designed by architect Boyan Chinkov and built in 1931, it was used for communist propaganda during performances in the town square. After 1989, "Orela" was restituted to the Boev family, who have preserved it to this day.

These photo collages convincingly illustrate the need to revisit the perception of Asenovgrad and go back in time in order to revive the memory of the old center, now irretrievably lost. As Vukov and Toncheva write, “...objects or buildings are made and adapted, damaged and reshaped in every culture, but that these acts gain special meaning in transitional periods where new notions of collective memory are being elaborated and 
new grounds for reworking or preserving the traces of the recent past exist" (Vukov and Toncheva, 2006, p. 125).

The destruction of the historical centers of the cities in Bulgaria during socialism is a tendency analyzed by the Bulgarian architect Todor Bulev: "We need to be much more critical of the projects for reconstructing central parts in this period. Again, we have proposals genetically related to the Athens Charter - a major reshaping of the old centers, enlarging the size of buildings, resized spaces, monofunctional areas and sites, but it is well known that the thinking of functionalism in relation to historical cores has been sharply criticized and denied by the people, but also by the architects and urban planners. These anti-historical and anti-social tendencies were very forcefully represented in competitions for the centers of Sofia, Varna, Burgas, and Plovdiv" (Bulev, 2015, p.39). ${ }^{16}$

In the course of my research, I found that the way the local architecture is perceived depends a great deal on the generational experience of the respondents. For example, from conversations with Asenovgrad residents, representatives of generations that remember socialism and even the era prior well revealed that they would have preferred to see the old center preserved. They pointed to an alternative location for positioning the new square - on the opposite bank of the Chaya River flowing through the town.

In relation to the topic, Emilia Koleva ${ }^{17}$ shared the following memories on the town's urban history: "Emblematic names of the town's culture lived on "Stălbena" Street. On the corner lived Dr. Svetozar Toshev, a private practitioner, historian, publicist, and documentary writer who came to Asenovgrad with the sole patriotic goal of working for the Bulgarian language. Upstairs lived the bookseller Dimitar Andreev"Gandhi", there lived the artist Bai Petko Lambrev and other urban families. If this iconic street had been preserved, it would have been the town's attraction. The library is now built here, but it is in a high and awkward place, on the third level, and people with disabilities do not have access to this building. It is modern, it is big, it is multifunctional, but it is steep, and it must be on a comfortable and suitable terrain, where there is access for many more people. The architectural plan and appearance, which has been realized and is currently functioning, is uniform. It is characteristic of the typical socialist construction. In recent years, construction of the new buildings next to the "Asenovets" hotel has violated the aesthetic aspects, as the dialogue between the square and the mountain and between the square and the historic Asen's Fortress is lost. The old center, the old buildings, the old shops - everything had to be preserved in order to have a memory and to live with this different old culture. And the new center-moved beyond the river, as it is all over the world, the old squares are preserved, and the new one is positioned on another more remote terrain. Now the romance of the town is missing, the cobblestones, the market halls, the monuments, the carriages, the trees, the fountains, the

\footnotetext{
${ }^{16}$ This quote taken from an original publication in Bulgarian is translated by the author.

${ }^{17}$ Emilia Koleva (born 1958) is a journalist with a MA in library and cultural management. For many years, she has been the head of the "Fine Arts" Department in the town library - part of the architectural ensemble in the center.
} 
confectioneries, the "făsha"18, the inns, and the tripe eateries have long since disappeared from the shady square...."19

These shared opinions demonstrate the need to revise previous urban planning solutions and find a new approach to public spaces. Asenovgrad socialist-era town center is still partially preserved, but some of the representative buildings are painted with graffiti. As of September 2020, the mosaics on the upper levels were severely damaged in places and the space around the buildings was generally ruined and neglected. From the middle of September 2020, the town square is being intensively repaired as part of a project estimated to cost over BGN 4 million. The beginning of the two-year-long reconstruction was inaugurated by the Mayor of Asenovgrad, Dr. Hristo Grudev, on September 3, 2020. The event was covered by the national and local media; it was also announced on the website of the Municipality of Asenovgrad. ${ }^{20}$

\section{From architecture and ideology to heritage tourism}

Power relations $^{21}$, the relations of subordination and hierarchy between the people and the ruling party elites are clearly evident in the planning and construction of Bulgarian cities during socialism. Much more than in other periods of Bulgarian history, the state purposefully and sustainably imposed an ideological regime by organizing the urban space and subordinating it to party principles and functions. In this way, a lasting impact on people's attitudes and perceptions was achieved and their connection with the past was severed. The natural development of the urban environment, which arose as a result of generations of accumulated human experience, was disrupted.

What is the essential relationship between architecture and ideology? According to Miodrag Šuvaković:

[A]rchitecture is essentially a political and ideological practice that uses its techno-aesthetic and techno-artistic strategies to participate in the organization of individual and collective human life, as well as in representing the symbolic and imaginary field of visibility of a society for itself and others. Except in rare instances of totalitarian political practices, the techno-aesthetic and techno-artistic

\footnotetext{
18 "Făsha" was a popular name of two pavilions for the sale of juices called "făsh".

${ }^{19}$ I received this statement written by Emilia Koleva via e-mail on March 2, 2020 as a result of a prior informal conversation I had with her on the topic.

${ }^{20}$ See the report from the TV program "Bulgaria in 60 minutes" on BNT from November 10, 2020: https://bnt.bg/news/remontirat-osnovno-centara-na-asenovgrad-v278770-286246news.html
}

The announcement on the website of the Municipality of Asenovgrad from September 3, 2020 stated: "Dr. Grudev pointed out that this is one of the most significant projects that will be implemented during his term due to the fact that the central part of Asenovgrad, used by all residents and guests of the town, is being repaired. He described the main interventions on the 3 square levels, noting that the most important of them is the second - the slab above the former shopping center. It will be completely destroyed because it is compromised and dangerous. In its place a new one will be laid. It will accommodate a permanent open stage with a service building, rock gardens and an amphitheater recreation area. It is also planned to replace the pavement, complete the drainage system, have new street and site lighting installed, including lighting the surrounding public buildings - "Paisii Hilendarski" Town Library, the Municipal Administration and the regional directorate of the Ministry of Interior. A video surveillance system, complete landscaping of the newly formed green areas, irrigation system and facilities providing accessibility for people with disabilities will be constructed": https://www.asenovgrad.bg/bg/novini/kmetat-na-asenovgrad-dr-grudev postavi-nachaloto-na-remonta-na-tsentralniya-ploshtad /

${ }^{21}$ For a discussion on power relations vis-à-vis architecture, see Sudjic, (2006). 
modalities of architecture hide its political and ideological character. (Šuvaković, 2014, p.10)

The architectural epoch of socialism marked the beginning of the reorganization of society according to the party ideology which aimed to abolish class structure. The representative socialist realist buildings, monuments and industrial/residential zones expressed the victory over the "old and obsolete" (Berbenliev, 1987, p.298). These structures located in the Eastern Bloc and all over the post-soviet space have recently been labeled "socialist heritage", "ruins of communism", and are now included into the touristic infrastructure of the post-socialist market economies. ${ }^{22}$ The commercialization of the socialist heritage has become a research field encompassing heritage studies, historical tourism and material culture. ${ }^{23}$

\section{Conclusion}

In this case study on the "socialist" urban center, I have demonstrated how the "ideological landscape" of Asenovgrad was created through architectural expressions in the second half of the twentieth century. The inherited material culture of this period is characterized by megalomania, in particular enlarging buildings to a scale that does not correspond to the parameters of a small town. Thus, Asenovgrad and its inhabitants were deprived of their cultural specificity as well as cultural markers that distinguish them from all others. Eventually, the urban culture and memory were depersonalized, interrupting cultural continuity between generations. Material culture does not consist only of collections of objects and building ensembles - it contains memories about ways of behavior and life. It is this cultural layer that was destroyed with the creation of the new town center.

In Asenovgrad, the "ideological landscape" of socialism is somewhat broken by several surviving old buildings in the town center which were built before 1945. Among them are the family houses designed by the renowned Bulgarian architect Boyan Chinkov. His Art Nouveau projects are still reminiscent of the old town architecture. However, other similar buildings have already been irretrievably lost and destroyed in order to erase the memory of the culture and urban lifestyle of Asenovgrad's inhabitants.

Recently, civil society organizations such as Stanimashka fotografchiynitsa are paying more attention to the relationship between the urban environment and the culture of memory. This is also a fine example of a bottom-up approach to influence current urban planning policies of the local authorities in favor of the public interest and supporting causes of shared value. During socialism (and for most of human history), urban governance and planning were in the hands of elites - therefore, people did not have direct access to these management policies. After 1989, citizens and their

\footnotetext{
${ }^{22}$ Recently, the architecture from the socialist era attracts tourists from abroad and is still an undeveloped segment of the tourist market in our country. On November 14, 2020, I participated in a walking tour in the center of Plovdiv, organized by Free Tour Plovdiv, and dedicated to the "socialist architecture and monumental art". These thematic guided walks, which have recently been organized for the interested public, offer a new look at the forsaken legacy of socialism and emphasize its existence in a post-socialist context. During the tour we visited the Central Post Office, the former Party House, the "Cosmos" Cinema, the Ivan Vazov" Library “, and the "Boris Hristov"Cultural House.

${ }^{23}$ For a discussion on the mechanisms of memory culture and the commercialization of the socialist heritage from the period of the People's Republic of Poland (PRL) in today's Warsaw, see Balcerzak, 2021.
} 
associations have become increasingly influential as a corrective to local governments in Bulgaria. Is the monumental center of Asenovgrad recognized as a valuable heritage? Or is it more an example of the unwelcome, negative legacy that residents cannot be reconciled with? The people of Asenovgrad give an unambiguous answer to this question - socialism has destroyed the old town center in order to impose and "create" a town square foreign to the local traditions and urban culture of Asenovgrad. Thus the culturalhistorical continuity has been interrupted and the achieved effect is seen in the alienation of citizens from their urban environment through which they could no longer identify themselves.

\section{References}

Balcerzak, A. (2021). "The Charm of the PRL". Memory Culture, (Post)Socialist Nostalgia and Historical Tourism in Poland, Slovenský národopis, 69(2), 255273, DOI: https://doi.org./10.2478/se-2021-0014

Berbenliev, P. (1987). Arhitekturnoto nasledstvo po balgarskite zemi. Sofia: Darzhavno izdatelstvo „Septemvri” [The Architectural Heritage of the Bulgarian Lands. Sofia: State Publishing House "Septemvri"].

Bulev, T. (2015). Balgarskoto gradoustroystvo 1944-1989, Arhitektura, (4), 36-41 [The Bulgarian Urban Planning 1944-1989, Architecture, (4), 36-41] Retrieved from https://bularch.eu/bg/broy-4-2015 Accessed February 252020.

Koeva, M. (1985). Metod za sistemno izuchavane na arhitekturnoto nasledstvo. Sofia: Balgarska akademiya na naukite [Method for systematic study of architectural heritage. Sofia: Bulgarian Academy of Sciences].

Harbova, M. (2003). Arhitekturnite znatsi na sotsializma - obezlichavane, otchuzhdavane, gigantomantiya. - V: Ivanova, R. Luleva, A., Popov, R. (sast.) Sotsializmat - realnost $i$ ilyuzii. Etnologichni aspekti na vsekidnevnata kultura. Sofia: Etnografski institut s muzey - BAN, 224-230 [The Architectural Signs of Socialism - Depersonalization, Alienation, Gigantomania. - In: Ivanova, R. Luleva, A., Popov, R. (ed.) Socialism - reality and illusions. Ethnological aspects of everyday culture. Sofia: Ethnographic Institute with Museum - BAS, 224-230].

Kaleva, E. (2015). Sotsialisticheskite pametnitsi i obshtestvenite gradski prostranstva V postsotsialisticheskiya balgarski grad. - Arhitektura, (3), 18-23. [Socialist Monuments and Public Urban Spaces in the Post-Socialist Bulgarian City. Architecture, (3), 18-23.]

Retrieved from https://bularch.eu/bg/broy-3-2015/ Accessed February 252020.

Kępa, M. (2015). 9 Architectural Icons of Communist Poland, 25 Sep 2015. Culture.pl. Accessed 29 Oct 2021. https://culture.pl/en/article/9-architectural-icons-ofcommunist-poland

Kostadinov, K. (1986). Asenovgrad. Sofia: Darzhavno izdatelstvo „Septemvri““ [Asenovgrad. Sofia: State Publishing House "Septemvri"].

Lahusen, T. (2006). Decay or Endurance? The Ruins of Socialism. Slavic Review, 65(4), 736-746. doi:10.2307/4148452

Lefebvre, H. (2009). Space and the State. - In: Brenner, N., Elden, S. (eds.). State, Space, World: Selected Essays / Henry Lefebvre, University of Minnesota Press, 223-253. 
Luleva, A. (2018). Heroes and Monuments. Local Projections of the National Memory in Bulgaria - In: Vukov, Nikolai, Svetla Kazalarska (eds.). Heroic Art and Socialist Realism: Monuments, Memory, and Representations of the Socialist Past after 1989. Sofia: Cultural Arcs Foundation, 183-201.

Nikolov, I. (2003). Panelniyat blok - realnost bez ilyuzii. - V: Ivanova, R. Luleva, A., Popov, R. (sast.). Sotsializmat -realnost $i$ ilyuzii. Etnologichni aspekti na vsekidnevnata kultura. Sofia: Etnografski institut s muzey - BAN, 113-119 [The panel block - reality without illusions. - In: Ivanova, Radost, Ana Luleva, Rachko Popov (eds.). Socialism - reality and illusions. Ethnological aspects of everyday culture. Sofia: Ethnographic Institute with Museum - BAS, 113-119].

Stanoeva, E. (2016). Sofia: ideologiya, gradoustroystvo i zhivot prez sotsializma. Sofia: Prosveta. [Sofia: ideology, urban planning and life during socialism. Sofia: Prosveta].

Sudjic, D. (2006). The Edifice Complex: How the Rich and Powerful Shape the World. Penguin Books.

Šuvaković, M. (2014). General Theory of Ideology and Architecture - In: Mako, V., Blagojevič, M. R. and Lazar, M. V. (eds.). Architecture and Ideology. Cambridge Scholars Publishing, 2-12.

Torre, L. (2020). Eastern Bloc Architecture: Trailblazing Churches and Controversial City Buildings, 19 Aug 2020. ArchDaily. Accessed 29 Oct 2021. https://www.archdaily.com/945948/eastern-bloc-architecture-trailblazingchurches-and-controversial-city-buildings

Vasileva A. \& Kaleva E. (2018). Live or Let die: Post-Socialist Public Space in The Context of Its Socialist Monuments - In: Vukov, Nikolai, Svetla Kazalarska (eds.). Heroic Art and Socialist Realism: Monuments, Memory, and Representations of the Socialist Past after 1989. Sofia: Cultural Arcs Foundation, 269-281.

Vukov, N. (2018). Sacred Chronologies and Lines of Continuities with Preceding Epochs in the Monuments after 1944 in Bulgaria- In: Vukov, Nikolai, Svetla Kazalarska (eds.). Heroic Art and Socialist Realism: Monuments, Memory, and Representations of the Socialist Past after 1989. Sofia: Cultural Arcs Foundation, 9-31.

Vukov, N. \& Toncheva, S. (2006). Town Squares and Socialist Heritage: the Reworking of Memorial Landscapes in Post-socialist Bulgaria - In: Schröder-Esch, Sebastian, Justus H. Ulbricht (eds.). The Politics of Heritage and Regional Development Strategies. Actors, Interests, Conflicts. vol. 2. Weimar: Bauhaus University, 121-136. 